
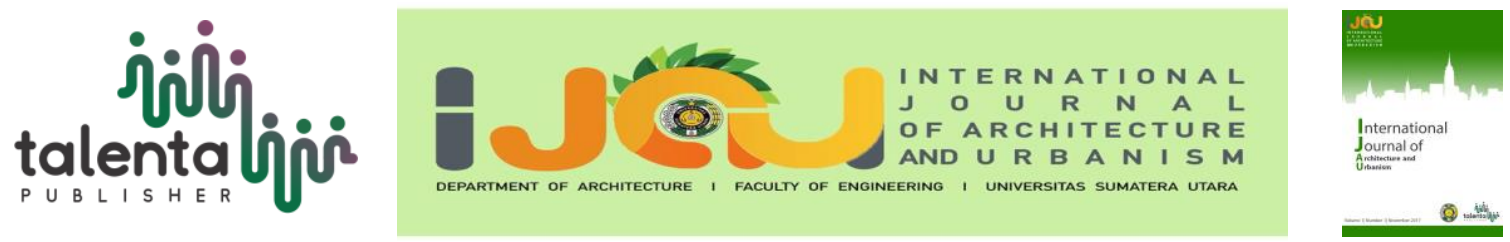

\title{
The Design Museum of Mount Sinabung with Neo- Vernacular Architecture Approach
}

\author{
Wahyuni Zahrah $^{1 *}$, Ade Syahputra Astono ${ }^{1}$ \\ ${ }^{1}$ Architecture Department, Faculty of Engineering, Universitas Sumatera Utara, Medan, Indonesia.
}

\begin{abstract}
Mount Sinabung is a volcano on the plateau of Karo Regency, North Sumatra, Indonesia. Mount Sinabung suddenly erupted in 2010. The last eruption of the volcano occurred since February 19, 2018, and until now become an attraction to find out more about volcanic disasters. Museum Mount Sinabung is present to provide the means for education, dissemination of information in the aspect of the volcano and geological disaster with recreative and educative of nature. The problem raised was "How to design a volcano museum using the neo-vernacular architectural approach?". By applying one flow that develops in this post-modern era to revive memories of a semi-historical culture, representational, plural and eclectic cultural Agenda on to evoke the Design of Museum Mount SinabungIn the application of the neo-vernacular architectural approach to the building of the Museum, the principle of building the Siwaluh Jabu is restored, physically and non-physically.By using the qualitative method of designing the Museum, it was designed because it was rational and planned systematically with the selected location. So, the Museum is conceptualized with a flexible gallery that can be used as a shelter for refugees. Thus, it is expected that the Museum can be a recreational-educational facility and as a means of supporting disaster mitigation.
\end{abstract}

Keyword: architecture, educational, museum, mount, recreational.

\section{Introduction}

Ring of fire was formed by volcanic arcs and oceanic trenches partly floating in the Pacific. Ring of fire has more than 452 more volcanoes where there are 129 active status mountains and does not cover the possibility of the volcanoes are inactive (dead) will change its status to become active. That number is nearly 13 percent of the total of active volcanoes in the world. Indonesia at the moment in the world's most active earthquake Mountain because it is surrounded by a ring of fire and when the above three kinds of collision of the continent, namely, Indo-Australia from the South, Eurasia from the North, and the Pacific from the East

\footnotetext{
*Corresponding author at: Architecture Department, Faculty of Engineering, Universitas Sumatera Utara, Perpustakaan St. J07 Building, Medan, 20155, Indonesia

E-mail address: Adesyahputraastono@gmail.com
} 
[1]. These geographic conditions make Indonesia disaster-prone areas as volcanic eruptions, earthquakes, and tsunamis but on the other hand, make Indonesia the regions fertile and rich in biodiversity. Dust a volcanic eruption fertilize the soil so that the community remains many who live in the area around the volcano. Therefore, it takes a number of mitigation efforts to reduce casualties when disaster struck. And the disaster mitigation effort into our shared responsibility. One of the volcanoes in Indonesia that are still active is Mount Sinabung. Mount Sinabung is Volcano on the plateau of Karo Regency, North Sumatra, Indonesia. Mount Sinabung mount Sibayak along nearby are two active volcanoes in North Sumatra's highest peak and became the 2nd in the province. The altitude of this mountain is $2.451 \mathrm{~m}$. Mount Sinabung has never recorded to erupt since the year 1600, but suddenly active again with a broke out in 2010 [2]. The last eruption of the volcano occurred since 19 February 2018 and lasts up to now. The eruption of Mount Sinabung is attracting the attention of researchers and the public to learn more about mount Sinabung. To accommodate the curiosity scientists (researcher) and the public need a place that recreativeeducative as well as the site of Mount Sinabung regard conservation and mitigation efforts to reduce the number of casualties due to disasters of Mt. Sinabung volcano and other geological disasters. Museum mount Sinabung is present to provide the means for education, dissemination of information in a particular aspect of the volcanoes and other geologic disaster that is recreative-educative to the wider community with the goal of providing insight and understanding about the scientific aspect, as well as socio-cultural and other things related to volcanoes and other geologic disaster source. Based on the background described, the aim in designing Museum mount Sinabung, namely to create a Museum of Volcanology with Neo-Vernacular Architecture approach.

\section{Literature Review}

This title describes the sense of quiet title terminology, overview theme, interpretation of the theme, and the theme of linkages towards the title. Which will be described in detail in the following.

\section{Terminology}

According to Government Regulation No. 66 RI year 2015 about museum Chapter (1) verse (1) paragraph (1), the Museum is an institution that serves to protect, develop and utilize collection, communicate to the community [3]. According to the website http://volcano.si.edu/, Mount Sinabung is one of the mountains on the plateau of Karo Regency, North Sumatra, Indonesia with type a stratovolcano with many lava flows on the sides. With the highest peak of 2,460 meters above sea level which becomes the highest peaks in North Sumatra. This mountain has not erupted since the year 1600 was recorded. Then the Museum Mount Sinabung is a building which serves to protect, develop, utilize, 
conserve collection, and communicate to the public and academics to study needs, education and interest on volcano, in particular, mount Sinabung and other geological disasters.

\section{Preview theme}

The word vernacular means local language, whereas Neo word comes from the Greek meaning new. So the Neo-Vernacular (KBBI) can be interpreted as the local language spoken in a new way [4]. According to Jenck (1990) is Neo-Vernacular Architecture is an application of existing architectural element, both physical and non-physical with the aim of preserving the local elements that have developed empirically by a tradition which was then a little or a large number of experienced renewal towards the more modern works without prejudice to local tradition [5].

\section{Interpretation of the Theme}

According to Erdiono (2011), there are four approach model to watch out for is related to form and meaning in design and modernizing the traditional buildings in the present context, as follows the first is the form and meaning of fixed. The appearance of the form and its architectural remains of the old form of adopting and duplicating (albeit with some changes in building materials) and meaning (cosmology, mythology, and genealogy) remains the same. And second is the form fixed with new meaning. The appearance of architectural creations remain to adopt and duplicate the long form but was given a new meaning. And the third is a new form with fixed meaning. The appearance of a new form of presenting architecture in the sense of old elements, if not off at all since going on a new interpretation of the old form against then given meaning to avoid surprises culture (culture shock.) and the fourth is Form and the meaning of new. The appearance of architectural creations presents a new form with new significance accompanied anyway because changing the paradigm of architecture in total [6].

\section{Correlation the theme with the title}

The Museum is a museum that Sinabung informs everything about mount Sinabung and surrounding areas. People living near Mount Sinabung is thick with the local culture. Karo culture is still very strong in this area. So apply the neo-vernacular architecture to lift a building belonging to the Karo culture museum mount right to apply as the architectural approach. With the approach applied to neo-vernacular architecture in designing the Museum this mount Sinabung, communities are expected to feel the culture of Karo in the Museum, although mount Sinabung is packed with more modern.

\section{Metodology}


The design method of the Museum of Mount Sinabung with recreational uses qualitative methods because they are really true and truly in accordance with The situation and location conditions of the design chosen.

Problem-solving methods are obtained by 1) Problem identification is identifying problems found in usable design land looking for the best solution for architectural design; 2) Problem formulation is formulated problems identified and make potential planning land to be analyzed becomes an advantage for design; 3) Design objectives understand the intent and purpose of design to obtain guidelines and the design orientation to be achieved both for users and the surrounding environment; 4) Data collection is data collection is a process of procuring primary data for design requirements. Data collection is an important step in scientific methodology because in general the data is collected will be used.

Data collection is done by 1) Field Survey / Primary Data Collection; 2) Study of literature and the; 3) analysis. As for the analysis carried out is; a) Site analysis; b) Design analysis; c) Function analysis; d) Activity analysis; e) User analysis; f) Analysis of space programs; g) Structure analysis; h) Design concept; j) Pre-design and; k) Final design.

\section{Result and Discussion}

Museum mount of Sinabung located in Karo district with the majority of the tribal society Karo. With the application of neo-vernacular architecture, the Museum of Mount Sinabung applying some elements of culture Karo, as follows the first one is Siwaluh Jabu traditional house. Siwaluh Jabu traditional house will be applied to the building Museum mount Sinabung as a mass and faces of the building but with shapes and more modern material (Figure 1).

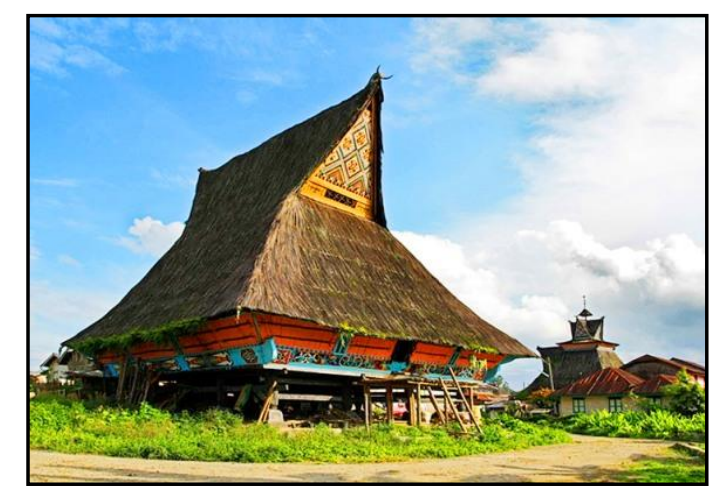

Figure 1. Siwaluh Jabu traditional house 
And the second is the Cosmology of Karo's people. Karo community also knows the existence of the three worlds, namely the world over as the divine world, the world as experienced by the human world, the underworld that is the world of death (Figure 2).

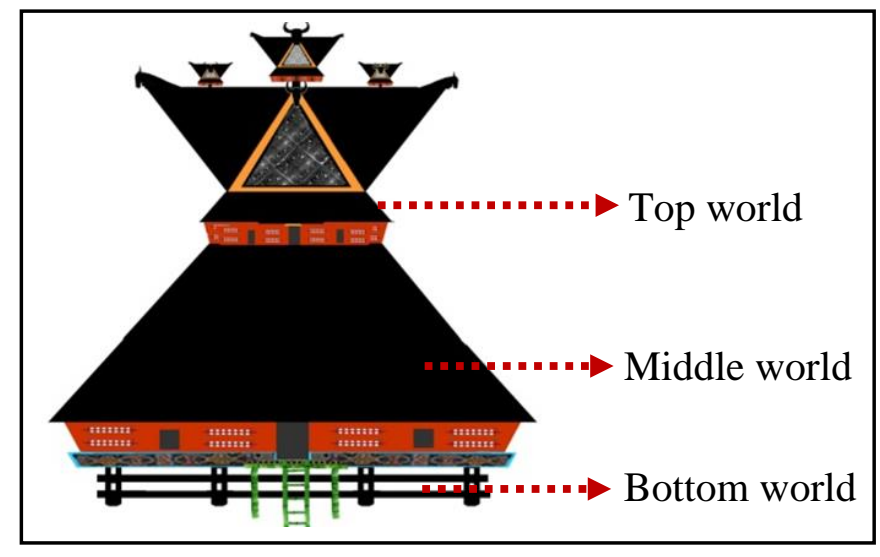

Figure 2. The Cosmology of Karo's people

And the third is Karo's ornament. Application of woven Ayo-ayo on the agenda in the traditional house according to the public Agenda as a talisman and symbol decoration applied in Museum mount Sinabung but with modern materials (Figure 3).

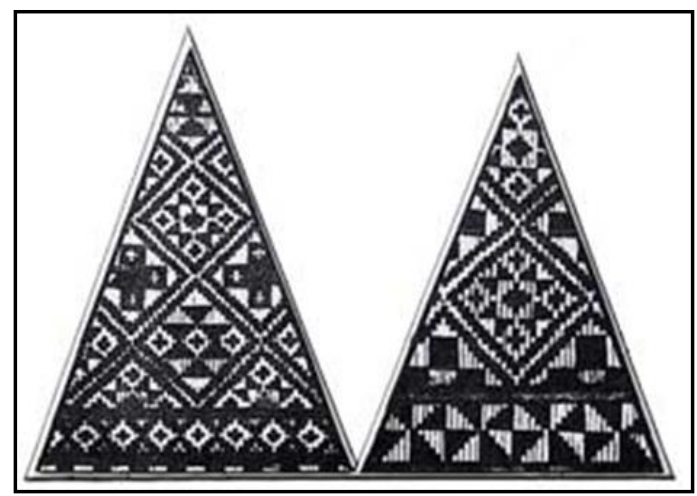

Figure 3. Woven Ayo-ayo

Of all the explanations above about neo-vernacular architecture can be summed up as shown in table 1 as follows:

Table 1. The results of the analysis of the application ofNeo-vernacular architecture

\begin{tabular}{lll}
\hline MUSEUM of & MOUNT SINABUNG & \\
\hline Criteria & Local form & $\begin{array}{l}\text { Yes, SiwaluhJabu traditional } \\
\text { house }\end{array}$ \\
\hline & Local belief & $\begin{array}{l}\text { Yes, Cosmology of Karo's } \\
\text { people }\end{array}$ \\
\hline & Traditional-Modern combination & $\begin{array}{l}\text { Yes, Traditional-modern material } \\
\text { concept }\end{array}$ \\
\hline Hallmark & Communicative & Yes \\
\hline
\end{tabular}




\begin{tabular}{lll}
\hline & Historical value & Yes \\
\hline Urban context & Yes \\
\hline Ornament technique & Yes, Ayo-ayo ornament \\
\hline Represents the overall & Yes, \\
\hline Metaphoric & No \\
\hline Plural & $\begin{array}{l}\text { Yes, Linkages local Architecture } \\
\text { and modern }\end{array}$ \\
\hline Concept & Eclectic & Yes \\
\hline & Roof ridge & No \\
\hline & Brick Material & Yes \\
\hline Traditional form & Yes, Mass conception \\
\hline Interior and exterior unity & Yes \\
\hline & Contrast color & Yes, Elegant color
\end{tabular}

\section{Mass conception}

The concept of mass building Museum mount Sinabung upon approach to the theme apply the theme to the application of Neo-vernacular architecture implements the concept of building Siwaluh Jabu applies traditional society, Karo. And also the Design Museum mount Sinabung is applying the concept of an Adaptive building against the tread. The building was designed to not impede the mount Sinabung, that visitors can date back to the grandeur of the building of the Museum and also mount Sinabung itself (Figure 4).

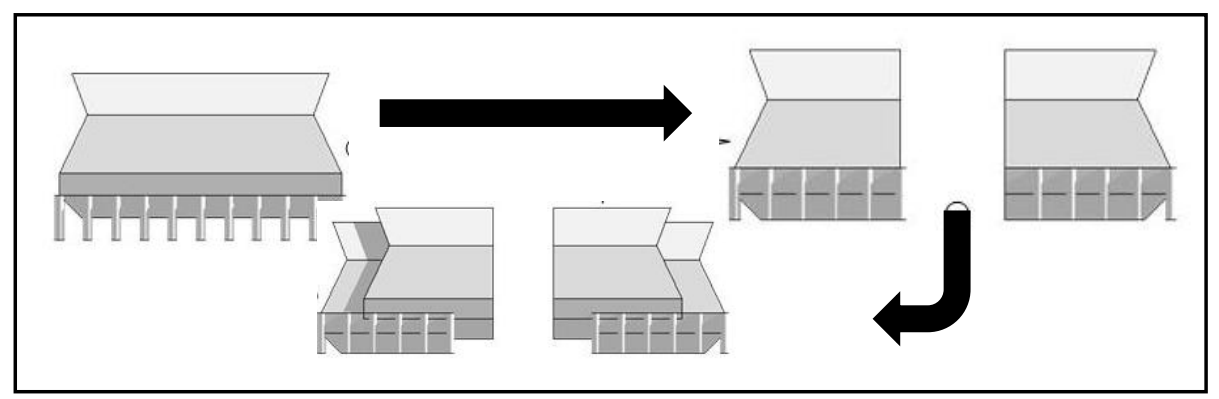

Figure 4. Mass conception

\section{Outdoor concept}

The concept of the Design Museum Mount Sinabung (Figure 5) i.e. Adaptive toward the tread. In its application, mount Sinabung remains the Foundation of the elements of building a Museum of Mount Sinabung itself. The building was designed by creating a view with the axis of the vista toward mount Sinabung. 


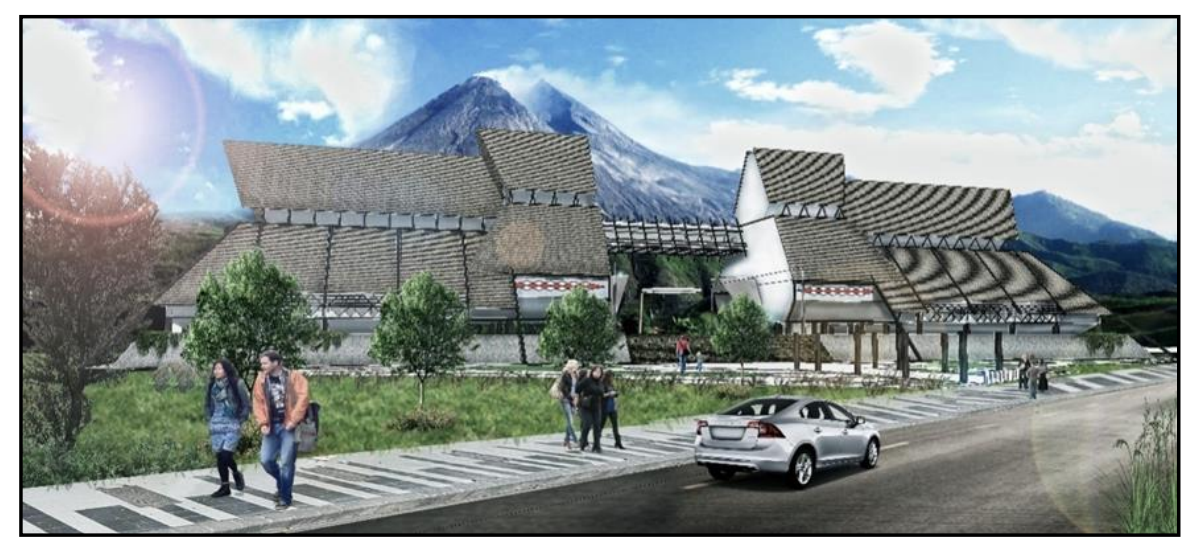

Figure 5.Design Museum Mount Sinabung

\section{Indoor concept}

The design museum mount Sinabung uses the concept of flexibility in spaces of functions. Where the room gallery on the museum's functions can be modified at any time when required as disaster shelters (Figure 6). The color purple showroom gallery which is used under normal circumstances. The color red is an extra room that expands the gallery when the eruption of Mount Sinabung disaster to accommodate evacuation disaster victims.

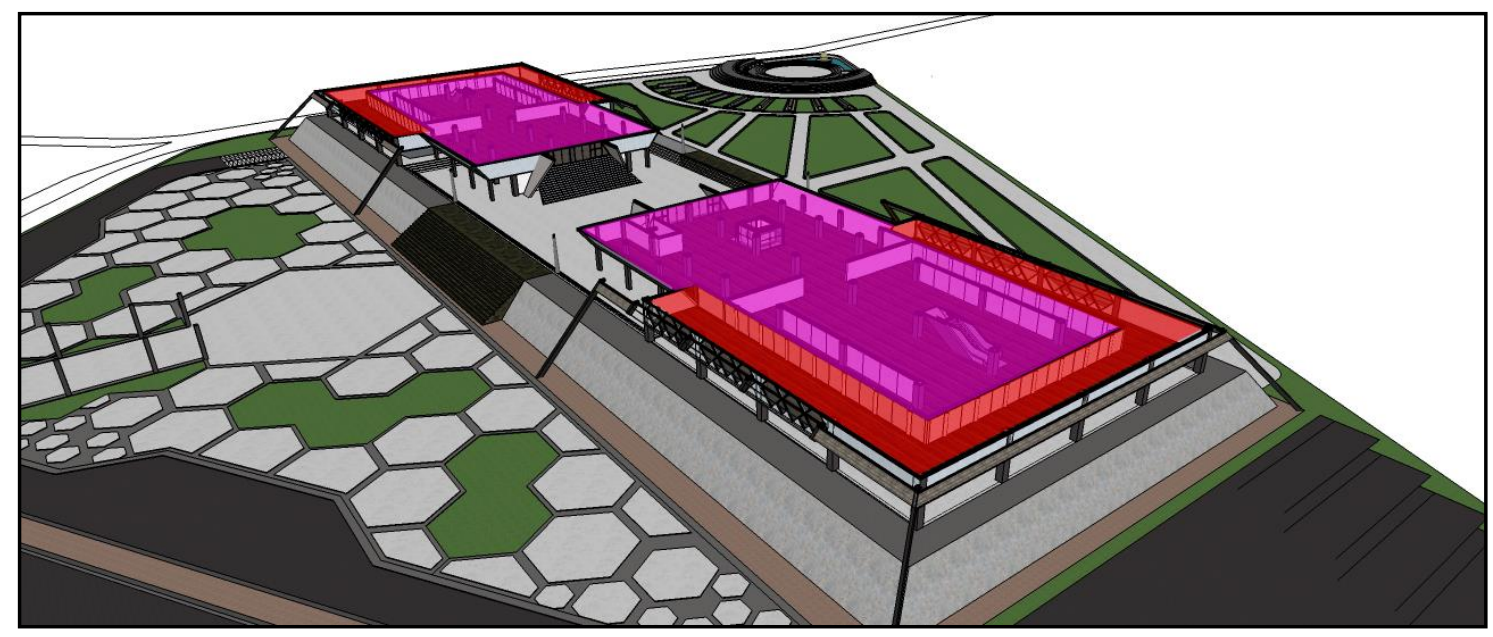

Figure 6. Flexibility space zone

\section{System Structure}

The concept of the structure of the building Museum Mount Sinabung using the same structure with the structure of a traditional house Siwaluh Jabu that is rigid-frame structure systems or Rigid Frame (Figure 7). 


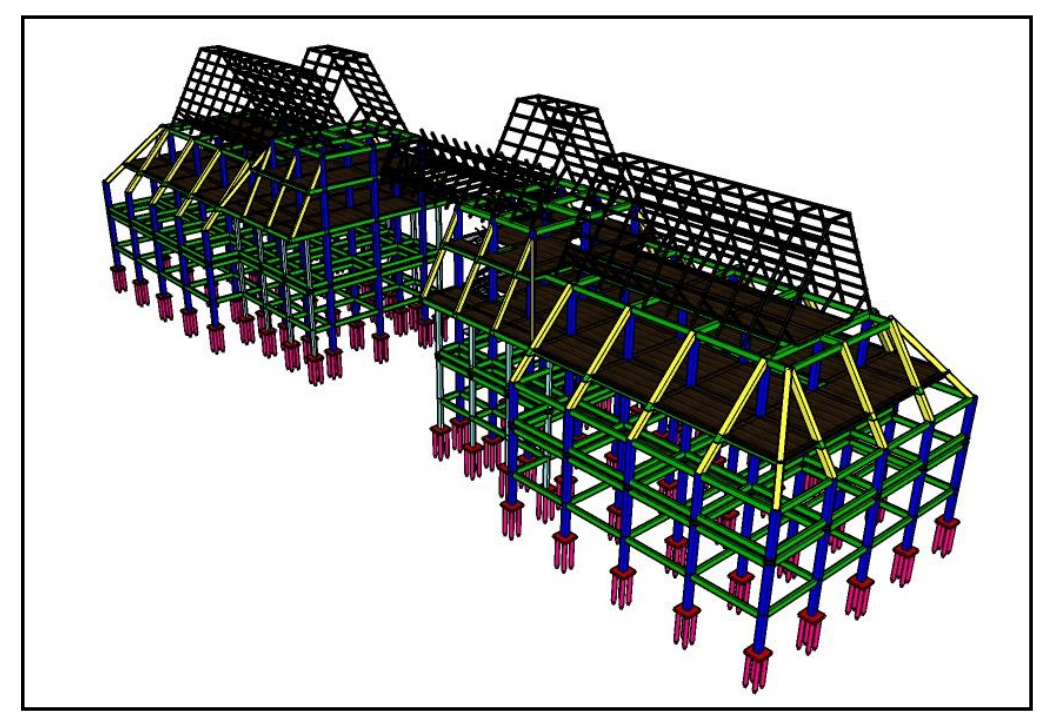

Figure 7. The structure of Museum Mount Sinabung

The Museum also apply an adaptive concept to the site, where the location of the Museum site on Mount Sinabung it prone to earthquake volcanic. This earthquake will be very influential towards the building. So the Museum mount Sinabung using the structural system that can reduce the impact of jolts earthquake against the building. Then, Museum of Mount Sinabung using Rubber Bearing isolation system (Figure 8). The use of these natural rubber bearing capable of reducing the impact of earthquake reaction of up to $70 \%$.

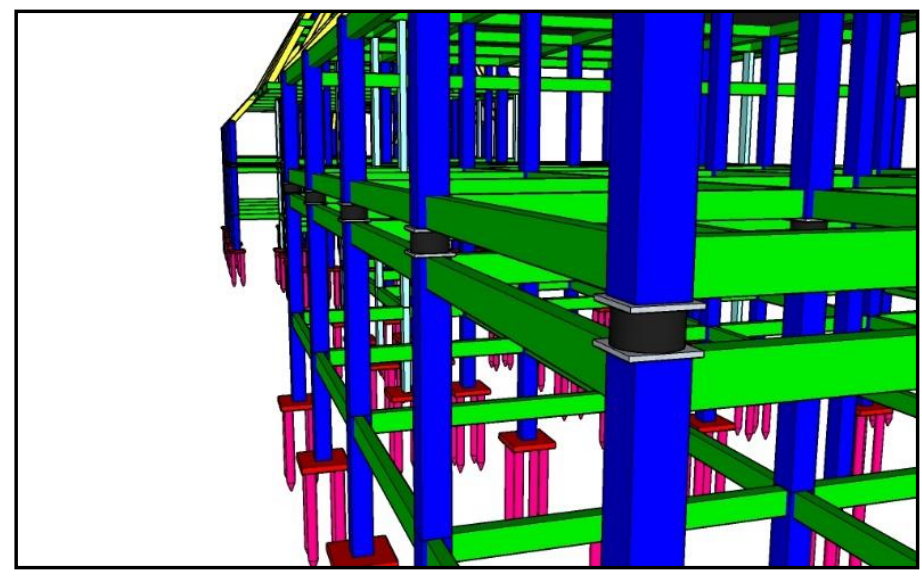

Figure 8. Rubber bearing isolation system

\section{Conclusion}

The Design Museum mount Sinabung is expected to become a vehicle of education that is both recreative and educative in terms of dissemination of information about volcanoes to the community. Using the approach of neo-vernacular architecture, the architectural flow developing in this post-modern era restore memory historical Karo community about culture. By applying the concept of flexibility of space as well as the principles of space on building custom Siwaluh Jabu is applied into the Design Museum mount Sinabung can be designed a 
space that can be used flexibly or can modify at any time when necessary. So, the Museum of Mount Sinabung was not only functioned as a gallery but when an eruption on Mount Sinabung Museum can disable townhouse as evacuation shelters and places the health post and the receipt of assistance social.

\section{Acknowledgement}

This research is aim to learn about Museum Vulcanology and provide solutions for developing tourism and supporting disaster mitigation in Karo Regency.

\section{REFERENCES}

[1] S. I. "Smithsonian Institution National Museum of Natural History. Global Volcanism Program. Department of Mineral Sciences.," 2013. [Online]. Available: http://volcano.si.edu/. [Accessible 2 April 2018].

[2] A. M. Pherson, "Mount Sinabung Volcano Eruptss in Indonesia Dicplaces 20,000.," [Online]. Available: http://nationalgeographic.co.id. [Accessible 2 April 2018].

[3] P. R. I. "Peraturan Pemerintah Republik Indonesia No.66," Jakarta, 2015.

[4] T. R. P. B. "Kamus Besar Bahasa Indonesia," 2008. [Online]. Available: http://kamusbahasaindonesia. org/ . [Accessible 2 April 2018].

[5] J. Charless, Language of postmodern architecture., New York: Rizzoli, 1990.

[6] D. Erdiono, “Arsitektur 'Mordern' (Neo) Vernakular di Indonesia,” Sabua, vol. III, no. 2085-7020, pp. 2-39, 2011. 